\title{
Faktor Risiko Terjadinya Coronavirus Disease 2019 (Covid-19) pada Penyandang Diabetes Melitus Tipe 2
}

\author{
Pomantow A. L. Roeroe, ${ }^{1}$ Bisuk P. Sedli. ${ }^{2}$ Octavianus Umboh ${ }^{2}$
}

${ }^{1}$ Program Studi Pendidikan Dokter Fakultas Kedokteran Universitas Sam Ratulangi, Manado, Sulawesi Utara, Indonesia

${ }^{2}$ Bagian Ilmu Penyakit Dalam Fakultas Kedokteran Universitas Sam Ratulangi, Manado,

Sulawesi Utara, Indonesia

Email: leosroeroe@gmail.com

\begin{abstract}
Coronavirus Disease 2019 (COVID-19) is an infectious disease caused by SARS-CoV2 and has been declared as a pandemic by WHO in March 11, 2020. This disease is an additional problem in people with type 2 diabetes mellitus (T2DM). Several studies have shown that diabetes is a risk factor for COVID-19. This study was aimed to determine the risk factors for the occurrence of Coronavirus Disease 2019 (COVID-19) in T2DM patients. This was a literature review study using several journal databases, namely Google Scholar, PubMed, and Science Direct. Literature searching was performed by using the PICOS method and the analysis was carried out qualitatively The results obtained 10 literatures reporting that T2DM would increase the severity and mortality of COVID-19 patients related to elderly age, obesity, chronic systemic inflammation, increased coagulation activity, potential direct damage to the pancreas, changes in expression of ACE2 receptors, dysregulation of the number, activity of immune cells, alveolar dysfunction, and endothelial dysfunction. There was not yet strong evidence regarding discontinuation or continuation of various diabetes drugs in COVID-19 patients, but insulin remains the recommended agent for blood glucose control. In conclusion, T2DM increases the severity and mortality rate of COVID-19 patients
\end{abstract}

Keywords: diabetes mellitus; COVID-19; risk factors

\begin{abstract}
Abstrak: Coronavirus Disease 2019 (COVID-19) merupakan salah satu penyakit infeksi yang disebabkan oleh SARS-CoV-2 dan telah ditetapkan sebagai pandemi oleh WHO pada 11 Maret 2020. Penyakit ini menjadi masalah tambahan bagi penyandang diabetes melitus tipe 2 (DMT2). Beberapa penelitian menunjukkan bahwa diabetes merupakan salah satu faktor risiko terjadinya COVID-19. Penelitian ini bertujuan untuk mengetahui faktor risiko terjadinya COVID-19 pada penyandang DMT2. Jenis penelitian ialah literature review menggunakan laporan penelitian dari beberapa database jurnal, yaitu google scholar, PubMed, dan ClinicalKey. Pencarian artikel menggunakan metode PICOS dan analisis dilakukan secara kualitatif. Hasil penelitian mendapatkan 10 laporan penelitian yang melaporkan bahwa DMT2 meningkatkan tingkat keparahan dan mortalitas pasien COVID-19 akibat adanya mekanisme terkait dengan usia lanjut, obesitas, peradangan sistemik kronis, peningkatan aktivitas koagulasi, potensi kerusakan langsung pankreas, perubahan ekspresi reseptor ACE2, disregulasi jumlah dan aktivitas sel imun, disfungsi alveolar, dan disfungsi endotel. Belum terdapat bukti kuat mengenai penghentian atau pelanjutan berbagai obat diabetes pada pasien COVID-19, tetapi insulin tetap menjadi obat yang disarankan untuk mengontrol glukosa darah. Simpulan penelitian ini ialah DMT2 meningkatkan tingkat keparahan dan mortalitas dari pasien COVID-19.
\end{abstract}

Kata kunci: diabetes melitus tipe 2 (DMT2), COVID-19, faktor risiko 


\section{PENDAHULUAN}

Coronavirus Disease 2019 (COVID19) dinamai oleh organisasi World Health Organization (WHO) untuk gejala penyakit jenis coronavirus. Penyakit ini merupakan jenis penyakit menular yang disebabkan oleh severe acute respiratory syndrome coronavirus 2 (SARS-CoV-2). Virus ini berhubungan dengan penyakit pernapasan yang terkait wabah 2002-2003 severe acute respiratory syndrome coronavirus 1 (SARS-CoV-1). ${ }^{1}$. Pada tanggal 30 Januari 2020 WHO menyatakan wabah COVID-19 sebagai Public Health Emergency of International Concern (PHEIC), dan pada 11 Maret 2020 WHO dinyatakan sebagai pandemi. $^{2}$

Puncak wabah transmisi virus menjadi lebih parah di seluruh dunia yang menunjukkan karakteristik pandemi. Wilayah Eropa menjadi pusat penyebaran dimulai pada tanggal 28 Maret 2020, yang menyebar ke 199 negara di seluruh dunia, dengan kumulatif 462.684 diagnosis yang dikonfirmasi di seluruh dunia. Jumlah individu terinfeksi yang dikonfirmasi di Amerika, Italia, Spanyol, Jerman, Prancis, Iran telah melebihi 20.000. ${ }^{3}$ Indonesia melaporkan kasus pertama pada tanggal 2 Maret 2020. Jumlah kasus meningkat dan menyebar dengan cepat ke seluruh wilayah Indonesia. Sampai dengan tanggal 6 Desember 2020 Kementerian Kesehatan melaporkan sebanyak 575.796 kasus konfirmasi COVID-19 dengan 474.771 telah dinyatakan sembuh dan sebanyak 17.740 yang meninggal. ${ }^{4}$

Coronavirus menyebar terutama melalui tetesan droplet, kontak langsung atau tidak langsung, dan dalam skala terbatas, transmisi aerosol. Waktu rerata dari paparan hingga timbulnya gejala ialah 5 hari, dan $97,5 \%$ orang yang mengalami gejala dalam 11,5 hari. Gejala yang paling umum ialah demam, batuk kering, dan sesak napas. ${ }^{5}$ Spektrum klinis COVID-19 beragam, mulai dari gejala mirip flu ringan hingga sindrom gangguan pernapasan akut, kegagalan banyak organ, dan kematian. Usia tua, diabetes dan penyakit penyerta lainnya dilaporkan sebagai prediktor bermakna dari morbiditas dan mortalitas. ${ }^{6}$ Peradangan kronis, pening- katan aktivitas koagulasi, gangguan respons imun, dan potensi kerusakan langsung pankreas oleh SARS-CoV-2 mungkin menjadi salah satu mekanisme yang mendasari hubungan antara diabetes dan COVID-19. ${ }^{7}$

Diabetes melitus (DM) adalah penyakit gangguan metabolik yang memengaruhi kerja insulin dalam penyerapan glukosa. Penyakit ini juga menjadi ancaman kesehatan internasional, yang tingkat keparahannya meningkat dalam dua puluh tahun terakhir. ${ }^{8}$ Diabetes merupakan salah satu faktor risiko utama terjadi COVID-19. Penyandang diabetes rentan terhadap infeksi karena hiperglikemia, gangguan fungsi kekebalan, komplikasi vaskular dan penyakit penyerta seperti hipertensi, dislipidemia, dan penyakit kardiovaskular. Tingkat keparahan dan mortalitas dari COVID-19 secara bermakna lebih tinggi pada pasien dengan diabetes dibandingkan pasien non-diabetes. Akibat penurunan fungsi kekebalan tubuh penyandang diabetes menjadi salah satu faktor pencetus mudanya terjadi COVID-19 di masa pandemi ini. ${ }^{9}$

Oleh karena itu, orang dengan penyakit bawaan DM dapat menjadi masalah yang serius di masa pandemik COVID-19. Berdasarkan latar belakang yang telah dipaparkan maka penulis memandang perlu melakukan penelitian literature review untuk membahas dan menelaah berbagai informasi ilmiah mengenai faktor risiko terjadinya COVID19 pada penyandang DMT2. ${ }^{10}$

\section{METODE PENELITIAN}

Penelitian ini merupakan suatu literature review melalui media dalam dan luar jaringan (daring dan luring) dimulai pada periode September hingga November 2020. Kata kunci yang digunakan dalam pencarian literatur yaitu "faktor risiko COVID-19 dan diabetes melitus tipe 2" dan kata kunci dalam Bahasa Inggris "factor Risk COVID19 and type 2 diabetes mellitus".

\section{HASIL PENELITIAN}

Pada penelitian ini didapatkan sebanyak 73 artikel menggunakan Pubmed, 394 artikel menggunakan ClinicalKey dan 119 artikel menggunakan Google Scholar 
( $\mathrm{n}=586$ ) yang sesuai kata kunci tersebut. Kriteria inklusi dalam penelitian ini ialah komunitas COVID-19 dengan penyakit penyerta DM tipe 2. Jenis penelitian ialah clinical trial, randomized controlled trial, systematic review dan meta analisis, dengan tahun publikasi 2020 serta berbahasa Inggris dan Indonesia. Kriteria eksklusi yakni komunitas COVID-19 tanpa penyakit DMT2 dan literatur yang tidak tersedia fulltext.
Hasil pencarian yang sudah didapatkan kemudian dilakukan skrining berdasarkan judul yang sesuai dengan topik literature review dan didapatkan 20 artikel $(\mathrm{n}=20)$. Selanjutnya 20 artikel diskrining abstrak dan fulltext berdasarkan kriteria inklusi dan ekslusi dan didapatkan 10 artikel $(n=10)$ literatur untuk digunakan dalam penelitian ini. Tabel 1 memperlihatkan hasil kajian 10 artikel yang dipakai dalam penelitian ini.

Tabel 1. Hasil kajian literatur mengenai diagnosis sindrom hepatorenal

\begin{tabular}{|c|c|c|c|}
\hline No & Judul dan Penulis & $\begin{array}{c}\text { Metode } \\
\text { Penelitian }\end{array}$ & Hasil Penelitian \\
\hline 1 & $\begin{array}{l}\text { Hussain et al, (2020). } \\
\text { COVID-19 and diabe- } \\
\text { tes: knowledge in } \\
\text { progress, }\end{array}$ & $\begin{array}{l}\text { Systematic } \\
\text { review }\end{array}$ & $\begin{array}{l}\text { - Usia tua, diabetes dan penyakit penyerta } \\
\text { lainnya dilaporkan sebagai prediktor } \\
\text { signifikan dari morbiditas dan mortalitas } \\
\text { - } \text { Peradangan kronis, peningkatan aktivitas } \\
\text { koagulasi, gangguan respons imun, dan } \\
\text { potensi kerusakan langsung pankreas oleh } \\
\text { SARS-CoV-2 mungkin menjadi salah satu } \\
\text { mekanisme yang mendasari hubungan } \\
\text { antara diabetes dan COVID-19 } \\
\text { - Tidak ada bukti konklusif untuk } \\
\text { mendukung penghentian per } \\
\text { - Tidak ada bukti konklusif untuk } \\
\text { mendukung penghentian penghambat } \\
\text { enzim pengubah angiotensin (ACEI), } \\
\text { penghambat reseptor angiotensin (ARB), } \\
\text { atau thiazolidinedion karena COVID-19 } \\
\text { pada pasien diabetes }\end{array}$ \\
\hline 2 & $\begin{array}{l}\text { Tadic et al (2020). }{ }^{11} \\
\text { COVID- } 19 \text { and diabe- } \\
\text { tes: is there enough } \\
\text { evidence? }\end{array}$ & $\begin{array}{l}\text { Systematic } \\
\text { review }\end{array}$ & 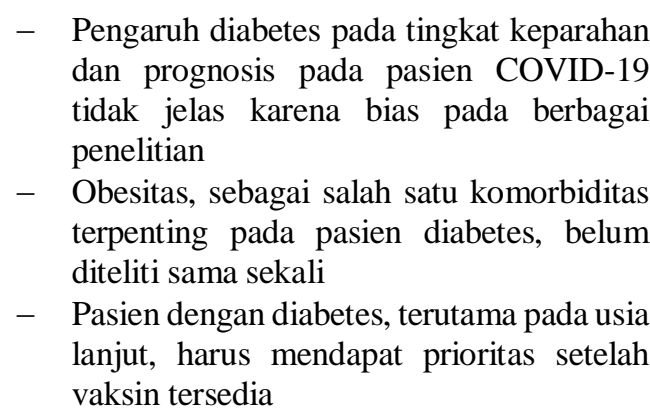 \\
\hline 3 & $\begin{array}{l}\text { Singh et al, }(2020))^{12} \\
\text { Diabetes in COVID-19: } \\
\text { prevalence, patho- } \\
\text { physiology, prognosis } \\
\text { and practical conside- } \\
\text { rations, }\end{array}$ & $\begin{array}{l}\text { Systematic } \\
\text { review }\end{array}$ & 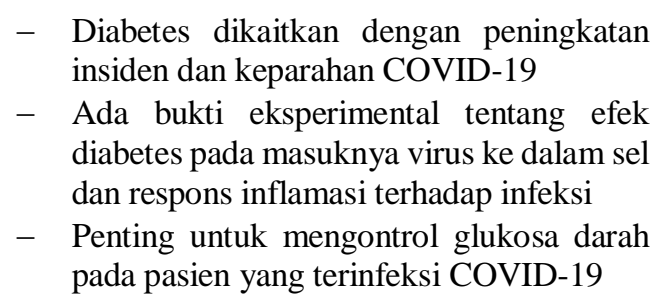 \\
\hline 4 & $\begin{array}{l}\text { Erener }(2020) .{ }^{13} \text { Diabe- } \\
\text { tes, infeet alction risk } \\
\text { and COVID-19 }\end{array}$ & $\begin{array}{l}\text { Systematic } \\
\text { review }\end{array}$ & $\begin{array}{l}\text { - Semakin banyak penelitian yang } \\
\text { menunjukkan diabetes sebagai faktor } \\
\text { risiko penting yang mempengaruhi } \\
\text { keparahan klinis dari infeksi Covid-19 } \\
\text { - Disregulasi jumlah sel imun dan } \\
\text { aktivitasnya memiliki peran penting dalam } \\
\text { memperburuk keparahan } \\
\text { - Kombinasi kondisi kronis yang juga }\end{array}$ \\
\hline
\end{tabular}




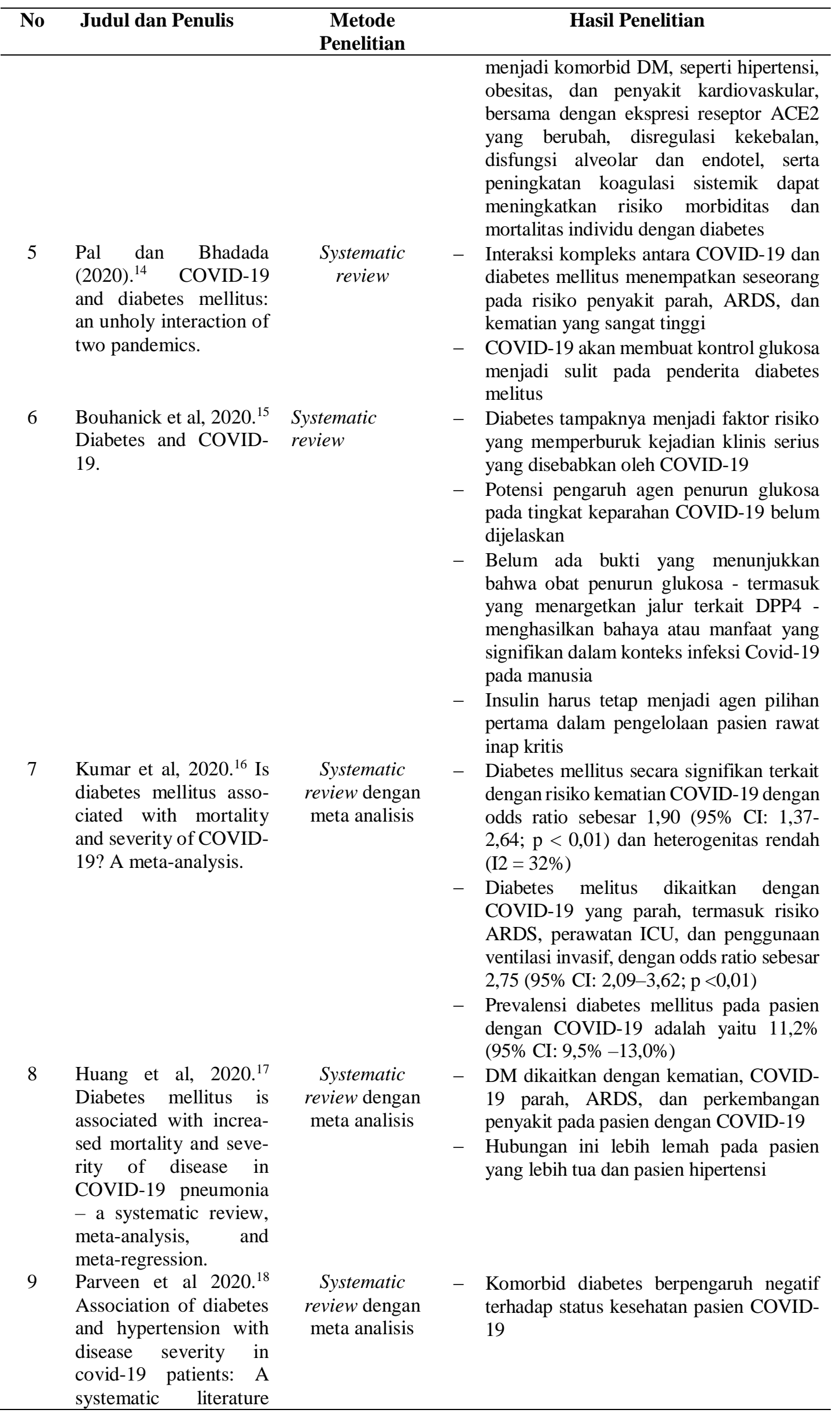




\begin{tabular}{llcl}
\hline No & Judul dan Penulis & $\begin{array}{c}\text { Metode } \\
\text { Penelitian }\end{array}$ & \multicolumn{1}{c}{ Hasil Penelitian } \\
\hline & $\begin{array}{l}\text { review and exploratory } \\
\text { meta-analysis. }\end{array}$ & & \\
10 & $\begin{array}{l}\text { Shang et al, 2020. }{ }^{19} \\
\text { Diabetes mellitus is } \\
\text { associated with severe }\end{array}$ & $\begin{array}{c}\text { Systematic } \\
\text { review dengan } \\
\text { meta analisis }\end{array}$ & $-\begin{array}{l}\text { DM dikaitkan dengan peningkatan risiko } \\
\text { infeksi parah dan kematian yang lebih } \\
\text { tinggi pada pasien dengan COVID-19 }\end{array}$ \\
infection and mortality & & \\
in patients with & & \\
COVID-19: a syste- \\
matic review and meta- \\
analysis.
\end{tabular}

\section{BAHASAN}

Hasi kajian artikel mendapatkan 10 laporan penelitian yang dapat digunakan untuk menjawab rumusan masalah penelitian ini. Diabetes melitus merupakan salah satu penyakit kronis yang bersifat katastrofik karena memiliki angka morbiditas dan mortalitas yang tinggi di seluruh dunia, baik di negara-negara maju, maupun di negara berkembang. Penyakit ini kemudian menjadi lebih penting untuk diperhatikan karena adanya pandemi COVID-19, suatu penyakit infeksi virus yang terutama menyerang saluran pernapasan. Sebuah kajian dengan meta-analisis yang dilakukan oleh Kumar et al $^{16}$ mendapatkan bahwa sebesar $11,2 \%$ pasien Covid-19 menyandang diabetes (95\% CI: 9,5\%-13,0\%). Berbagai penelitian pun telah melaporkan keterkaitan antara diabetes dengan COVID-19.

Sebuah kajian yang dilakukan oleh Parveen et $\mathrm{al}^{18}$ menunjukkan bahwa diabetes menyebabkan kondisi kesehatan umum pasien Covid-19 menjadi lebih buruk. Hasil ini didukung oleh tiga kajian berbeda yang dilakukan oleh Hussain et al, ${ }^{7}$ Bouhanick et al, ${ }^{15}$ dan Erener. ${ }^{13}$ Hasil dari ketiganya menunjukkan bahwa diabetes merupakan salah satu faktor penting yang memengaruhi tingkat keparahan dan mortalitas pasien Covid-19. Singh et al ${ }^{12}$ juga melaporkan sebuah kajian yang menunjukkan bahwa diabetes dikaitkan dengan peningkatan insiden dan tingkat keparahan Covid-19. Sebuah kajian dengan meta analisis oleh Kumar et al ${ }^{16}$ menunjukkan bahwa diabetes secara bermakna terkait dengan risiko kematian COVID-19 dengan odds ratio sebesar 1,90 (95\% CI: 1,37-2,64; $\mathrm{p}<0,01)$. Disebutkan juga bahwa diabetes dikaitkan dengan tingkat keparahan COVID-19 yang lebih parah, termasuk risiko ARDS, perawatan ICU yang lebih lama, dan penggunaan ventilasi invasif dengan odds ratio sebesar 2,75 (95\% CI: $2,09-3,62 ; p<0,01)$. Hasil ini juga sejalan dengan kajian yang dilakukan oleh Pal dan Bhadada, ${ }^{14}$ Huang et al, ${ }^{17}$ dan Shang et al. ${ }^{19}$ Ketiganya menunjukkan bahwa penyandang diabetes yang mengalami COVID-19 akan lebih berisiko untuk mengalami COVID-19 yang berat/parah, ARDS, hingga kematian. Hasil berbeda ditunjukkan pada sebuah kajian dengan meta analisis yang dilakukan oleh Tadic et $\mathrm{al}^{11}$ yang justru mendapatkan bahwa tingkat keparahan dan prognosis pada pasien COVID-19 yang memiliki komorbid diabetes tidak jelas karena adanya bias pada berbagai penelitian.

Mekanisme diabetes menyebabkan peningkatan morbiditas dan mortalitas pasien COVID-19 telah dilaporkan pada empat kajian yang digunakan pada penelitian ini. Hussain et $\mathrm{al}^{7}$ melaporkan bahwa hubungan antara diabetes dengan COVID-19 didasarkan pada mekanisme peradangan sistemik kronis, peningkatan aktivitas koagulasi, gangguan respons imun, dan potensi kerusakan langsung pankreas oleh SARSCoV-2. Erener ${ }^{13}$ juga melaporkan bahwa peningkatan risiko morbiditas dan mortalitas disebabkan oleh perubahan ekspresi reseptor ACE2, disregulasi jumlah dan aktivitas sel imun, disfungsi alveolar, disfungsi endotel, serta peningkatan koagulasi sistemik. Memperkuat hasil tersebut, Singh et $\mathrm{al}^{12}$ mendapatkan adanya penelitian eksperimental yang melaporkan bahwa 
diabetes mempermudah masuknya virus ke dalam sel dan membuat disregulasi respons inflamasi yang dimunculkannya.

Diabetes yang ditemukan pada individu berusia tua dan/atau individu yang mengalami komorbid lain, seperti hipertensi, juga turut meningkatkan morbiditas dan mortalitas dari pasien tersebut. Sebuah kajian yang dilakukan oleh Hussain et $\mathrm{al}^{7}$ mendapatkan bahwa usia tua, diabetes, dan penyakit penyerta lainnya merupakan prediktor bermakna dari morbiditas dan mortalitas pasien COVID-19. Sementara itu, kajian yang dilakukan oleh Huang et $\mathrm{al}^{17}$ melaporkan hasil sebaliknya. Dalam laporannya, disebutkan bahwa diabetes pada individu berusia tua dan/atau mengalami hipertensi memiliki hubungan yang lebih lemah dengan morbiditas dan mortalitas COVID-19 daripada individu yang berusia muda dan/atau tidak mengalami hipertensi. Uniknya, meskipun sebelumnya dinyatakan bahwa tidak terdapat bukti yang cukup untuk menunjukkan hubungan antara diabetes dengan COVID-19, Tadic et $\mathrm{al}^{11}$ tetap memberikan rekomendasi agar pasien diabetes berusia lanjut mendapatkan prioritas dalam pemberian vaksin COVID-19 setelah nantinya tersedia.

Terapi yang selama ini dijalani oleh penyandang diabetes pun menjadi perhatian ketika pasien mengalami Covid-19. Singh et $\mathrm{al}^{12}$ menyatakan bahwa penting untuk mengontrol glukosa darah pada pasien diabetes yang terinfeksi COVID-19 tetapi kondisi ini sulit untuk dilakukan, sebagaimana yang disebutkan dalam kajian oleh Pal dan Bhadada. ${ }^{14}$ Hal ini disebabkan masih tidak diketahui dengan jelas apakah terapi diabetes dan hipertensi boleh dilanjutkan atau dihentikan. Sebuah kajian yang dilakukan oleh Hussain et $\mathrm{al}^{7}$ menyebutkan bahwa tidak ada bukti konklusif untuk membuat rekomendasi apakah berbagai obat diabetes dan hipertensi boleh dilanjutkan atau dihentikan pada pasien COVID-19. Bouhanick et $\mathrm{al}^{15}$ juga mendapatkan bahwa pengaruh pemberian berbagai obat diabetes terhadap tingkat keparahan COVID-19 belum dapat dijelaskan. Belum terdapat bukti kuat yang dapat menunjukkan bahaya atau manfaat dari penggunaan obat tersebut pada pasien COVID-19. Meskipun demikian, insulin tetap menjadi agen pilihan pertama dalam pengelolaan glukosa pada pasien rawat inap dengan COVID-19.

Penelitian ini berbentuk literature review dan memiliki beberapa keterbatasan. Pertama, penelitian ini tidak menganalisis berbagai karakteristik subjek yang digunakan dalam penelitian yang dianalisis. Hal ini disebabkan karena tidak semua penelitian mencantumkan secara lengkap karakteristik subjek penelitiannya, sehingga penulis menganggap analisis karakteristik subjek tidak tepat bila dilakukan. Kedua, penelitian ini menggunakan laporan penelitian dengan desain systematic review. Hal ini terpaksa dilakukan karena terbatasnya laporan penelitian mengenai permasalahan yang diangkat oleh penelitian ini karena COVID-19 merupakan penyakit yang relatif baru.

\section{SIMPULAN}

Diabetes melitus tipe 2 akan meningkatkan tingkat keparahan dan mortalitas dari pasien COVID-19 akibat faktor-faktor risiko yakni akibat adanya mekanisme hubungan antara diabetes melitus dengan COVID19 terkait dengan usia lanjut, obesitas, peradangan sistemik kronis, peningkatan aktivitas koagulasi, potensi kerusakan langsung pankreas, perubahan ekspresi reseptor ACE2, disregulasi jumlah dan aktivitas sel imun, disfungsi alveolar, dan disfungsi endotel yang dapat secara tidak langsung memengaruhi ke arah komplikasi yang lebih parah akibat COVID-19. Belum terdapat bukti kuat mengenai penghentian atau kelanjutan dari berbagai obat diabetes pada pasien COVID-19, tetapi insulin tetap menjadi agen yang disarankan untuk mengontrol glukosa darah.

\section{Konflik Kepentingan}

Penulis menyatakan tidak terdapat konflik kepentingan dalam studi ini.

\section{DAFTAR PUSTAKA}

1. WHO. Anjuran mengenai penggunaan masker dalam konteks COVID-19. World Heal Organ. 2020;(April):1-17. 
2. Zhang R, Li Y, Zhang AL, Wang Y, Molina MJ. Identifying airborne transmission as the dominant route for the spread of COVID-19. Proc Natl Acad Sci U S A. 2020;117(26):14857-63. Available from: www.pnas.org/cgi/doi/10.1073/ pnas.2009637117

3. Chopra KK, Arora VK. Covid-19 and social stigma: Role of scientific community. Indian J Tuberc. 2020;67(3):284-5. Available from: https://doi.org/10.1016/ j.ijtb.2020.07.012

4. Slamet, Bratasena A, Rizkiyati N, Sitorus M, Samoedro E, Nadhirin, et al. Pedoman Surveilans dan Respon Kesiapsiagaan Menghadapi Middle East Respiratory Syndrome Corona Virus (MERS-CoV). Kementerian Kesehatan Republik Indonesia Direktorat Jendral Pengendalian Penyakit dan Penyehatan Lingkungan, 2013; Available from: https://www. kemkes.go.id/resources/download/pusk es-haji/2-Pedoman-surveilan-danrespon-kesiapsiagaan-menghadapimers-cov.pdf

5. Lam DSC, Wong RLM, Lai KHW, Ko CN, Leung HY, Lee VYW, et al. COVID19: Special precautions in ophthalmic practice and FAQs on personal protection and mask selection. Asia-Pacific J Ophthalmol (Philadelphia, Pa). 2020; 9(2):67-77.

6. Wiersinga WJ, Rhodes A, Cheng AC, Peacock SJ, Prescott HC. Pathophysiology, transmission, diagnosis, and treatment of coronavirus disease 2019 (COVID-19). JAMA. 2020;324(8):782. Available from: https://jamanetwork.com/journals/ jama/fullarticle/2768391

7. Hussain A, Bhowmik B, do Vale Moreira NC. COVID-19 and diabetes: knowledge in progress. Diabetes Res Clin Pract. 2020; 162:108142.

8. 8. Abdi A, Jalilian M, Sarbarzeh PA, Vlaisavljevic Z. Diabetes and COVID19: A systematic review on the current evidences. Diabetes Res Clin Pract. 2020;166:108347. Available from: https://doi.org/10.1016/j.diabres.2020.1 08347

9. Jeong IK, Yoon KH, Lee MK. Diabetes and COVID-19: Global and regional perspectives. Diabetes Res Clin Pract.
2020;166:108303.

10. Jayaweera M, Perera H, Gunawardana B, Manatunge J. Transmission of COVID19 virus by droplets and aerosols: A critical review on the unresolved dichotomy. Environ Res. 2020;188: 109819. Available from: https://doi.org/ 10.1016/j.envres.2020.109819

11. Tadic M, Cuspidi C, Sala C. COVID-19 and diabetes: Is there enough evidence? J Clin Hypertens. 2020;22: 943-8.

12. Singh AK, Gupta R, Ghosh A, Misra A. Diabetes in COVID-19: Prevalence, pathophysiology, prognosis and practical considerations. Diabetes Metab Syndr Clin Res Rev. 2020;14(4):303-10.

13. Erener S. Diabetes, infection risk and COVID19. Mol Metab. 2020;39:101044. Doi: 10.1016/j.molmet.2020.101044

14. Pal R, Bhadada SK. COVID-19 and diabetes mellitus: An unholy interaction of two pandemics. Diabetes Metab Syndr Clin Res Rev. 2020;14(4):513-7.

15. Bouhanick B, Cracowski J-L, Faillie J-L. Diabetes and COVID-19. Therapies. 2020;75(4):327-33.

16. Kumar A, Arora A, Sharma P, Anikhindi SA, Bansal N, Singla V, et al. Is diabetes mellitus associated with mortality and severity of COVID-19? A metaanalysis. Diabetes Metab Syndr Clin Res Rev. 2020 ;14(4):535-45.

17. Huang I, Lim MA, Pranata R. Diabetes mellitus is associated with increased mortality and severity of disease in COVID-19 pneumonia - A systematic review, meta-analysis, and metaregression: Diabetes and COVID-19. Diabetes Metab Syndr Clin Res Rev. 2020;14(4):395-403.

18. Parveen R, Sehar N, Bajpai R, Agarwal NB. Association of diabetes and hypertension with disease severity in covid-19 patients: A systematic literature review and exploratory meta-analysis. Diabetes Res Clin Pract. 2020;166:108295.

19. Shang L, Shao M, Guo Q, Shi J, Zhao Y, Xiaokereti J, et al. Diabetes Mellitus is associated with severe infection and mortality in patients with COVID-19: a systematic review and meta-analysis. Arch Med Res. 2020;51(7):700-9. 